\title{
Criminalization of Commercial Sex Workers and Service Users of Commercial Sex Workers in Criminal Law Renewal
}

\author{
Muhamad Khalif Ardi ${ }^{1}$, Supanto ${ }^{2}$; Rehnalemken Ginting ${ }^{2}$ \\ ${ }^{1}$ Master of Law Student, Faculty of Law, Universitas Sebelas Maret, Indonesia \\ ${ }^{2}$ Lecturer, Faculty of Law, Universitas Sebelas Maret, Indonesia \\ http://dx.doi.org/10.18415/ijmmu.v8i12.3203
}

\begin{abstract}
The purpose of this study is to look at the regulation of the actions of workers and service users of commercial sex workers in the current criminal law and to see the regulation of the actions of workers and service users of commercial sex workers in the future. This research is a normative research or doctrinal legal research using a statutory approach and a conceptual approach. The results of this study are that there is no clear regulation in Indonesian criminal law regarding criminal liability for the actions of workers and service users of commercial sex workers other than those contained in certain regional regulations, and in the future with the criminalization of acts of sexual intercourse outside the marriage bond as an act The criminal complaint in the Draft Criminal Code (RKUHP) must be changed into a form of ordinary crime so as not to limit the movement of law enforcement officers in carrying out law enforcement related to the actions of workers and users of commercial sex workers.
\end{abstract}

Keywords: Criminalization; Commercial Sex Workers; Service Users; Criminal Law Reform

\section{Introduction}

The rapid development of the era in the modern era has brought a huge impact on social life, both positive and negative impacts. In social life that is increasingly developing lately, social problems often arise that continue to grow, these social problems appear along with the times. One of the social problems that continues to grow and remains interesting to study until now, which is faced by the community as a result of the times is the problem of prostitution or commonly known as prostitution. Talking about prostitution is the same as talking about something classic, but because of the need to solve and overcome it to be resolved, it is always relevant to be discussed and studied in accordance with the development of the era and human civilization. (Mediaindonesia.com) The practice of prostitution or prostitution is still very common in everyday life and exists in almost every region in Indonesia, whether done openly or secretly. (Sulistyaningsih, and Jones, G.W, 1997) According to Bonger and Mudjijono prostitution is a social phenomenon when a woman provides herself for sexual acts as a livelihood. (Mamahit, 2010) Meanwhile, Commmenge and Soedjono view prostitution as an act in which a woman trades or sells her body, to obtain payment from men who come to pay for it and the woman has no other livelihood or livelihood except that which is obtained by having sex. moment with lots of people. (Amalia, 2016) 
The act of prostitution for the Indonesian people who adhere to the values of religious teachings as a way of life is an act that violates religious teachings and also violates moral norms, therefore the act of prostitution or prostitution is seen as a deviant act by the community. Religious teachings which are a way of life for the people of Indonesia are a manifestation of the implementation of Pancasila values, especially the value of the first precept, namely Belief in One God. Indonesia is a country whose ideology is based on Pancasila, as well as a country based on law. Indonesia as a state of law as stated in the provisions of Article 1 Paragraph (3) of the 1945 Constitution which reads "The State of Indonesia is a state of law", which results in every citizen having to obey and obey every applicable law and behave in accordance with the rules. applicable law, so that the law is binding on every action taken by its citizens.

The increasing prevalence of prostitution or prostitution in Indonesia of course in general can be motivated by various factors. Factors causing prostitution or prostitution in general are weak economic factors, low education factors, religious factors, environmental factors, weak moral values inherent in the perpetrators of prostitution or prostitution and the incomplete legal regulations governing prostitution or prostitution, especially related to regulations governing the service users of commercial sex workers and commercial sex workers themselves. If you look at the factors that cause it, then efforts to eradicate prostitution or prostitution must be carried out through approaches by studying the causes of its occurrence so that solutions can be obtained and appropriate action can be taken in eradicating prostitution or prostitution. .

Furthermore, for the occurrence of acts of prostitution or prostitution in practice there are parties involved in it. Parties involved are parties who play a role in the occurrence of acts of prostitution or prostitution, parties who play a role in the occurrence of prostitution or prostitution include, among others, pimps or pimps, commercial sex workers, and the service users of commercial sex workers themselves. Users and commercial sex workers as part of the parties who can bring about the occurrence of prostitution cannot be prosecuted legally, because in the current Criminal Code there is no single criminal provision that regulates users of prostitution services and commercial sex workers itself.

In the case of eradicating prostitution or prostitution, there are problems in it, these problems are related to the non-accommodation of commercial sex workers and users of commercial sex workers in the current Criminal Code. The Criminal Code as a positive criminal regulation currently in force in Indonesia in the provisions of Article 296 and Article 506 of the Criminal Code cannot ensnare the actions of prostitutes and their users, but only ensnare brothel owners, pimps, and brokers or brokers from acts of prostitution or prostitution. prostitution. Sentencing that is only oriented towards pimps, brokers, brokers or brothel owners, of course does not reflect a sense of justice, because in prostitution or prostitution for the occurrence of these acts there are subjects involved and interrelated in it, namely pimps or pimps, sex workers and users, so that the Criminal Code as an instrument of positive criminal law that applies nationally in Indonesia today can be said to be still unable to provide fair legal certainty and equal treatment before the law to parties involved in prostitution or prostitution.

The impact of the void of criminal norms at the national legal level which does not regulate the actions of commercial sex workers and users of commercial sex workers services as mentioned above is that in addition to causing punishment to be oriented only to brothel owners and pimps, it also does not provide a sense of justice for the perpetrators. the actors involved in it, so it will be difficult to eradicate prostitution or prostitution as a whole. Because the punishment does not touch the users and perpetrators of commercial sex workers because there are no rules that regulate it in the current Criminal Code. Based on this description, it is important for the Government of Indonesia to establish a new regulation relating to the criminal liability of workers and users of commercial sex workers in Indonesia. So the problems that will be studied in writing this article include knowing the regulation of the actions of commercial sex workers and users of commercial sex workers services in Indonesian criminal law today and trying to conceptualize the arrangements for the accountability of commercial sex workers and users of commercial sex workers services in the future. 


\section{Methods}

This research is a normative legal research or commonly referred to as doctrinal legal research. (Efendi and Ibrahim, 2016) The approach in this study uses a statutory approach (The Statue Approach) and a conceptual approach (conceptual approve). The statutory approach (The Statue Approach), is a research using an approach to study various legal rules related to the research problem. (Efendi and Ibrahim, 2016) The conceptual approach (conceptual approve) in this study is used to describe and analyze problems to find solutions and solve the problems studied. (Diantha, 2017)

\section{Discussion}

\section{Regulation of the Actions of Commercial Sex Workers and Users of Commercial Sex Workers in Indonesian Criminal Law}

Regulations regarding criminal acts in Indonesia today are not only regulated in the Criminal Code (KUHP) but are also widely regulated in laws and regulations outside the Criminal Code (KUHP). The Criminal Code (KUHP) as the parent of the enforcement of criminal law in Indonesia currently does not contain any regulations regarding criminal liability for commercial sex workers and service users of commercial sex workers who are involved in prostitution or prostitution, but only regulates the accountability of pimps and prostitution. brothel owner only. Article 296 of the Criminal Code (KUHP) only regulates the actions and responsibilities of pimps, while Article 506 of the Criminal Code only regulates the actions and responsibilities of the owner of a place that is used as a location for prostitution or prostitution (brothel). Meanwhile, the provisions for criminal acts and liability against workers and service users of commercial sex workers are not contained in it, so there is a legal vacuum (norms) in the Criminal Code (KUHP) relating to the actions and responsibilities of workers and service users of commercial sex workers. involved in prostitution or prostitution.

The impact of the legal vacuum (norms) related to the regulation of the actions and responsibilities of workers and service users of commercial sex workers who are involved in prostitution or prostitution in the Criminal Code (KUHP) makes punishment only possible and oriented to pimps and brothel owners without can touch workers and service users of commercial sex workers who are involved in prostitution or prostitution, this of course creates a sense of injustice in the application of crime or punishment to all parties involved in prostitution or prostitution because punishment cannot be carried out against workers and service users of sex workers because there are no regulations in the Criminal Code (KUHP) regarding the actions and responsibilities of workers and service users of commercial sex workers who are involved in prostitution or prostitution. Another impact of the legal vacuum (norms) related to the regulation of criminal acts and responsibilities of workers and service users of commercial sex workers who are involved in prostitution or prostitution in the Criminal Code (KUHP) makes law enforcement officers unable to take action against workers and service users. commercial sex workers who are involved in prostitution or prostitution because there are no regulations that regulate it, so this will make it difficult for workers and service users of commercial sex workers to be eradicated.

As for efforts to eradicate prostitution or prostitution that is rife in various regions in Indonesia and to criminalize commercial sex workers and users of commercial sex workers services that are not accommodated in the Indonesian Criminal Code, the government, in this case local governments can use regulatory policies which can be realized in local regulations (PERDA). Likewise, in efforts to eradicate prostitution in Mataram City and to avoid a legal vacuum in an effort to convict commercial sex workers and commercial sex workers in Mataram City, the Mataram City Government uses regulatory policies embodied in Mataram City Regional Regulation No. 11 of 2015 concerning Public Peace and Order, where in the regional regulation there are provisions of Article 29 Letters D and F which prohibits everyone from becoming a worker and user of commercial sex worker services, and if they continue to do 
the act, they will be given sanctions in accordance with the provisions of Article 44 Paragraph ( 1) the regional regulation, namely, in the form of a maximum imprisonment of six months and a maximum fine of fifty million rupiah. Actions related to the actions of workers and service users of commercial sex workers who violate the provisions of Article 29 Letters D and F can only be carried out as long as the actions of the workers and users of commercial sex workers services occur in the area of Mataram City only, whereas if the actions of the workers and service users of commercial sex workers are occurs outside the area of Mataram City, it cannot be enforced, this is because the regional regulation is regional, which means that the regional regulation only applies within a predetermined area, in this case it only applies in the Mataram City area, while in other areas in the city of Mataram. outside the city of Mataram following their respective regional regulations.

Other regulations relating to the regulation of criminal acts and accountability against commercial sex workers and users of commercial sex workers services, apart from being seen in regional regulations, can also be seen in various laws and regulations outside the Criminal Code (KUHP) as in Law No. 21 of 2007 concerning the Eradication of the Crime of Trafficking in Persons and in Law no. 11 of 2008 concerning Information and Electronic Transactions. In Law no. 21 of 2007 concerning the Eradication of the Crime of Trafficking in Persons, there are provisions in Article 12 that can be used to account for the actions of users of commercial sex workers who are victims of exploitation from the criminal act of trafficking in persons, the application of the provisions of Article 12 of Law no. 21 of 2007 concerning the Eradication of the Crime of Trafficking in Persons which contains a minimum imprisonment of three years and a maximum of fifteen years or a fine of at least one hundred and twenty million rupiahs and a maximum of six hundred million rupiahs. This can only be applied to users of commercial sex workers. as long as it is proven that the commercial sex worker is a victim of sexual exploitation as a result of the act of trafficking in persons, while the commercial sex worker cannot be held accountable for his actions because he is considered a victim of exploitation from the criminal act of trafficking in persons. Furthermore, in the provisions of Article 27 Paragraph (1) and Article 45 Paragraph (1) of Law no. 11 of 2008 concerning Information and Electronic Transactions can also be used to account for the actions of workers and service users of commercial sex workers. The provisions of Article 27 Paragraph (1) of Law no. 11 of 2008 concerning Information and Electronic Transactions is a provision that contains a prohibition for anyone to not intentionally and without rights distribute and/or transmit and/or make accessible Electronic Information and/or Electronic Documents that have content that violates decency, while the provisions Article 45 Paragraph (1) is a provision that contains a criminal threat in the form of imprisonment for a maximum of six years or a fine of a maximum of one billion rupiahs for any person who violates the provisions of Article 27 Paragraph (1) of Law no. 11 of 2008 concerning Electronic Information. In relation to the criminal liability of workers and service users of commercial sex workers, the provisions of Article 27 Paragraph (1) and the provisions of Article 45 Paragraph (1) can only be applied to commercial sex workers as long as it is proven that the commercial sex worker is promoting through electronic media and the user of the service. The commercial sex worker conducts transactions through electronic media to be able to use the services of the commercial sex worker.

\section{Regulation on the Liability of Commercial Sex Workers and Users of Commercial Sex Workers in the Future}

Conceptually, criminal responsibility is basically imposing a reproach on the perpetrator of a criminal act for his actions that have violated an act that has been prohibited or because his actions have resulted in a prohibited result. (Huda, 2011) To be criminally responsible for an act, the act must first be regulated in the provisions of the applicable laws and regulations, this is because there is a principle of legality as stated in Article 1 Paragraph (1) of the Criminal Code which reads: (Moeljatno, 2018) "no act can be punished except on the strength of the criminal rules in the legislation that existed before the act was committed". 
Based on these provisions, an act cannot be punished or criminally accounted for as long as there is no criminal provision that has previously regulated it. Seeing that an act cannot be punished or criminally accounted for without a rule that has regulated it, then criminal responsibility for the actions of workers and users of commercial sex workers cannot be carried out because there are no rules governing the act, so that in order to be able to ask for criminal responsibility against the actions of workers and service users of commercial sex workers who are involved in prostitution or prostitution must be criminalized first against the actions of workers and users of commercial sex workers services. (Islam, 2021)

In criminalizing the actions of workers and service users of commercial sex workers, at least it must be based on considerations of philosophical aspects, sociological aspects and juridical aspects. Philosophically, Pancasila is the only state ideology which is the main basis for implementing the main ideals of the state and is also the moral basis of the state. The central point of state morality contained in Pancasila is the value of divinity in which the teachings of God and human values are contained which give birth to natural law and ethical law which are the basis of thought for regulating the order of people's lives and at the same time are the basis of Indonesian legal philosophy, so that in such a sense Pancasila in essence it is the highest legal idea that will be the source of all legal sources in Indonesia (Ms noor and Bakry, 2001) and if divine values are part of the values contained in Pancasila which are used to assess the actions of commercial sex workers and service users commercial sex workers, then it appears that the act is contrary to the teachings of God, because it is an act that is prohibited in the teachings of God, so it is appropriate for the act to be criminalized under Indonesian law..

Sociologically, the actions of commercial sex workers and service users of commercial sex workers are considered a disease of society, even in some areas these acts are considered by the community as an act that pollutes the sanctity of society because it is contrary to the values that live and develop in society, in addition to polluting the sanctity of society. The actions of commercial sex workers and service users of commercial sex workers are also considered to have polluted the sacred and sacred values of marriage, so it is fitting for the perpetrators to be punished, this sociological reason of course provides reinforcement of the importance of criminalizing the actions of commercial sex workers and users of commercial sex workers under Indonesian law. Meanwhile, based on juridical considerations, criminalization of the actions of commercial sex workers and users of commercial sex workers services needs to be carried out considering that none of the provisions of the Indonesian criminal law currently in force regulates directly and firmly against the actions of commercial sex workers and service users of commercial sex workers.

In the future legal thought (ius constituendum) or the law aspired by the social life of the community and the state, but not yet as a rule of law in the form of laws or other regulations, namely the 2019 Draft Criminal Code (RKUHP) as a draft concept of the Criminal Code (KUHP) in the future although it does not explicitly regulate criminal acts and accountability for the actions of commercial sex workers and users of commercial sex workers, but the Indonesian government through the provisions of Article 417 Paragraph (1) The Draft Criminal Code (RKUHP) is seeking to criminalize acts of sexual intercourse outside the marriage bond, (https://www.dpr.go.id). The 2019 Draft Criminal Code, accessed on October 29, 2021) however, even though the act of sexual intercourse outside the marriage bond has been criminalized in the provisions of Article 417 Paragraph (1) of the Draft Criminal Code (RKUHP), it still raises This is a problem because the form of a criminal act as regulated in the provisions of Article 417 Paragraph (1) is a complaint crime, meaning that this limits the space for law enforcement officials to enforce the law against perpetrators who have sexual intercourse outside the marital bond directly because to can be held criminally responsible for the perpetrators who commit sexual intercourse outside the marriage bond, there must be a complaint first. In relation to the criminal liability of commercial sex workers and service users of commercial sex workers, the form of a criminal complaint in the provisions of Article 417 Paragraph (1) of the Draft Criminal Code (RKUHP) cannot be directly enforced by law 
enforcement officers because it must there is a complaint beforehand so that law enforcement can be carried out, this also limits the space for law enforcement officers in carrying out law enforcement against commercial sex workers and users of commercial sex workers, so that the form of a criminal complaint in the provisions of Article 417 Paragraph (1) of the Draft Book The Criminal Law Act (RKUHP) must be changed to become an ordinary crime so that law enforcement officers can enforce the law directly without any prior complaints against commercial sex workers and users of commercial sex workers.

\section{Conclusion}

Based on the research that the author did, in the end it was concluded that the regulation regarding the actions of commercial sex workers and service users of commercial sex workers in Indonesian criminal law currently does not have a firm regulation, so there is a legal vacuum, but in certain regional regulations there are regulations. concerning acts and criminal liability for the actions of commercial sex workers and users of commercial sex workers. Then, in the conceptual framework in the future with the renewal of criminal law with the establishment of the Draft Criminal Code (RKUHP) as the parent of future criminal law enforcement, criminalization of acts of sexual intercourse outside the marriage bond has been carried out, but because of the form of the act The crime is a complaint crime so that it limits the space for law enforcement officers in law enforcement against perpetrators of sexual intercourse outside the marriage bond, because law enforcement officers in law enforcement against perpetrators of sexual intercourse outside the marriage bond can only act if there is a complaint, so that the form of a criminal act This complaint must be turned into an ordinary crime, in relation to law enforcement against workers and service users of commercial sex workers. against workers and service users of commercial sex workers.

\section{References}

Anwar Sahid, Polemik Prostitusi Di Indoonesia Surat Kabar Harian Media Indonesia, Nomor XIII,13 Agustus, 2016,Hlm.6 Kolom 3. Di ambil Dari http://www.surat Kabar Harian Media Indonesia.com.

Chairul Huda, Dari Tiada Pemidanaan Tanpa Kesalahan Menuju Tiada Pertanggungjawaban Pidana Tanpa Kesalahan, Kencana, Jakarta: 2011.

Endang R Setyaningsih Mamahit, Perempuan-Perempuan Kramat Tunggak, Kepustakaan Populer Gramedia: Jakarta, 2010.

https://www.dpr.go.id. Rancangan Kitab Undang-Undang Hukum Pidana Tahun 2019, hlm. 100.

Hull,T.,, Sulistyaningsih, E,. Dan Jones, G.W., Pelacuran di Indonesia: Sejarah dan Perkembangan. Pustaka Sinar Harapan dan Ford Foundation: Jakarta, 1997.

I Made Pasek Diantha, Metodologi Penelitian Hukum Normatif Dalam Justifikasi Teori Hukum, Prenada Media Group, Jakarta: 2017.

Indonesia, Undang-Undang Dasar Negara Republik Indonesia Tahun 1945, Lembaran Negara Nomor 75 Tahun 1959.

Junaedy Efendi dan Johnyy Ibrahim, Metode Penelitian Hukum Normatif dan Empiris, Prenada Media Group, Depok: 2016. 
Mia Amalia, Analisis Terhadap Tindak Pidana Prostitusi Dihubungkan Dengan Etika Moral Serta Upaya Penanggulangan Di Kawasan Cisarua Kampung Arab, Jurnal Mimbar Justitia, Vol. II No. 2 Desember 2016.

Moeljatno, KUHP Kitab Undang Undang Hukum Pidana, Bumi Aksara, Jakarta: 2018.

Noor Ms dan Bakry, Orientasi Filsafat Pancasila, Liberty, Yogyakarta: 2001.

Yolanda Islamy, Upaya Kriminalisasi Terhadap Pengguna Jasa Prostitusi Dalam Perspektif Hukum Positif di Indonesia, Jurnal Ilmiah Galuh Justisi, Volume 9, Nomor 1, 2021.

\section{Copyrights}

Copyright for this article is retained by the author(s), with first publication rights granted to the journal.

This is an open-access article distributed under the terms and conditions of the Creative Commons Attribution license (http://creativecommons.org/licenses/by/4.0/). 